\title{
The impact of government outsourcing on public spending: evidence from European Union countries
}

Running title: The impact of government outsourcing on public spending

José M. Alonso ${ }^{\mathrm{a}}$, Judith Clifton ${ }^{\mathrm{a}, *}$ \& Daniel Díaz-Fuentes ${ }^{\mathrm{a}}$

${ }^{a}$ Department of Economics, University of Cantabria, Santander, Spain.

* Corresponding author:

Judith Clifton

Department of Economics

University of Cantabria

Avda. de los Castros s/n

39005 Santander, Spain

Tel: + 34942201287

E-mail addresses: alonsoajm@unican.es (José M. Alonso); judith.clifton@unican.es (Judith Clifton); daniel.diaz@unican.es (Daniel Díaz-Fuentes) 


\title{
The impact of government outsourcing on public spending: evidence from European Union countries
}

\begin{abstract}
Reducing public spending was a major objective when governments across Europe increasingly turned to outsourcing as a mode of public service provision from the 1980s. Today, despite its prevalence, there is still little consensus in the literature on whether outsourcing is an effective policy as regards reducing spending. Using a panel data model for 25 European countries over the period 1990 to 2011, this article tests whether outsourcing actually led to a reduction in public spending. Results indicate that outsourcing failed to reduce government expenditures at the central government level. This finding persists even after controlling for expenditure dynamics and addressing potential endogeneity issues.
\end{abstract}

Keywords: outsourcing, government expenditure, panel data, Europe

JEL Classification: C23, H10, H50, L33

\section{Introduction}

Government outsourcing - the transfer across to non-government organizations of the production of goods and services previously provided within government - remains a popular tool of government. Indeed, governments have increasingly turned to outsourcing over the recent period: outsourcing accounted for over 10\% of GDP across the OECD in 2011, up from 8.5\% in 2000 (OECD, 2011; OECD, 2013). Policy transfer across borders has intensified this trend: in the European Union (EU) increased efforts to coordinate and harmonise domestic policy on public services has led towards some convergence (Ferré, 2008). In particular, the European Commission (EC) has actively encouraged European governments to adopt outsourcing as a form of service delivery (Warner \& Clifton, 
2014) ${ }^{1}$. The Organization for Economic Cooperation and Development (OECD) also supports the extension of outsourcing policies to its thirty-five members (OECD, 2007).

Despite the increased popularity of outsourcing initiatives across the globe, there remain important gaps in our understanding of the dynamics of this widespread policy. Outsourcing has generated a vigorous, ideologically charged debate, as regards its benefits and drawbacks among scholars, policy-makers and international organizations. Outsourcing advocators claim that it induces cost savings and efficiency gains, particularly through the introduction of competition and the discipline of private ownership (Bel, Fageda, \& Warner, 2010; Boardman, Vining, \& Weimer, 2016). Governments typically justify outsourcing policies as a means to reduce overall costs to taxpayers. More recently, outsourcing has been justified as a part of a body of austerity measures during the ongoing crisis (Vaughan-Whitehead, 2013). Outsourcing has been presented as a means of facilitating governments' efforts towards fiscal consolidation to decrease their public deficits (Anderson, Hunt \& Snudden, 2014). However, it is not a foregone conclusion that outsourcing always generates cost savings of any kind. Economists, along with public policy and administration scholars, have provided a number of explanations for why government outsourcing may not reduce costs. In particular, sources of potentially greater costs for governments include the existence of high transaction costs, fiscal illusion problems, pressure from interest groups and negative externalities derived from outsourcing, such as employment reductions (Boyne, 1998a; Brown \& Potoski, 2005; Hefetz \& Warner, 2012; Sappington \& Stiglitz, 1987).

From an empirical standpoint, the precise effect of government outsourcing on overall public sector spending is not yet clear. The empirical literature on outsourcing is large, constituting a significant strand within public economics, public policy and public

\footnotetext{
${ }^{1}$ See EC new rules in public procurement: $\underline{\text { http://ec.europa.eu/internal_market/publicprocurement/index_en.htm }}$
} 
administration: useful reviews of the literature and meta-analyses include, Bel \& Warner, 2015; Bel et al., 2010; Domberger \& Rimmer, 1994; Domberger \& Jensen, 1997; Hodge, 2000; Jensen \& Stonecash, 2005; Savas, 2000, among others. However, few of these studies addressed the question of how cost savings resulting from outsourcing — if any — are passed back to the government as a whole (one exception is Alonso, Clifton, \& Diaz-Fuentes, 2015a). Hodge (2000) reported that, of the handful of studies on this topic, only scant support that cost savings from outsourcing translated into reduced government spending. In Hodge's (2000, p.110) words, “there is a worrying lack of evidence” supporting the logic that "reduced direct costs through contracts should, all other thing being equal, mean reduced costs overall to the government”.

To address this gap in the literature on the effects of government outsourcing, this paper offers one of the first studies investigating the assumption that contracting out public service production results in overall lower public spending for multiple countries over the medium term. The paper builds on the scarce body of studies of government outsourcing effects on overall government spending by expanding the number of countries analysed, controlling for potential endogeneity problems between outsourcing implementation and public spending, and by controlling for expenditure dynamics.

To do so, we borrow from the government contracting literature, and adopt an aggregate approach to understanding the effects of outsourcing, in order to attain a global perspective — at the central government level — on its effects across multiple countries. We assess the impact of government outsourcing on public sector spending across 25 European Union (EU) countries² over two decades, from 1990 to 2011, using panel data techniques. This aggregated approach may help to better understand the overall outsourcing effects despite differences found in specific cases.

\footnotetext{
${ }^{2}$ The sample consists on the EU-28 countries excluding Bulgaria, Croatia and Romania due to lack of reliable data to construct the outsourcing indicator.
} 
Our work has been facilitated by the publication of a number of new data sources. The previous lack of data on direct versus indirect service delivery which restricted research efforts (Minicucci \& Donahue, 2004) has been improved with the implementation from the late 1990s of the System of National Accounts (SNA), as well as the European System of Accounts (ESA). Our study has also been facilitated by the OECD's ongoing work on constructing indicators to evaluate how governments are performing (OECD 2011, 2013), from which we derive the outsourcing indicator.

The rest of the paper is organized as follows. We begin by discussing the main theoretical arguments on whether, how and why outsourcing might affect government expenditure. Next, we describe the data and the statistical model that is used for inference. The fourth section reports the estimation results and interprets them. Our results suggest that government outsourcing was not associated with lower government expenditure, regardless of the model used for inference. The policy implications of this finding are then explored, and conclusions follow.

\section{Outsourcing and government spending: theoretical expectations}

The classic justifications for outsourcing is that this reduces government costs, ultimately making government more efficient, a key policy objective desired by all taxpaying

citizens; however, several theoretical reasons exist which predict why this policy may or may not reduce public spending. 


\subsection{The null hypothesis: Government outsourcing leads to a reduction of public spending}

Two over-riding theoretical reasons explain why outsourcing should incur cost savings for governments: the pressure of competition and the discipline of private ownership, both issues extensively addressed by public choice and property rights theories (Bel et al., 2010; Ruiz-Villaverde, Picazo-Tadeo, \& Gonzalez-Gomez, 2015). Drawing on neoclassical economics, the public choice literature critiques governments' provision of public services because it assumes that politicians and government bureaucrats behave according to the typical neoclassical individual, who seek to maximize his or her profit and personal interests whilst neglecting the citizens they purportedly serve (Niskanen, 1971). In other words, bureaucrats' behaviour might be dominated by self-interest rather than public service motivation or altruism. Hence, in order to redirect public officials’ behaviour towards public interest, a pattern of incentives and/or constraints might be needed (Boyne, 1998b). The solution proposed by public choice proponents consists of forcing previously protected, in-house activities into a new environment characterized by market discipline and competition amongst potential public service providers. Competition is, therefore, one of the fundamental ideas justifying the practice of outsourcing, due to the potential cost savings generated by market forces (Savas, 2000); the distinctive feature of outsourcing is that service contracting is performed in a special type of marketplace, via a competitive bidding process. Following Domberger and Jensen (1997, p.68), in an outsourcing scenario, the market "is defined by the contract specification, and the bidding process resembles an auction”. This may generate an $e x-$ ante competition, whereby contracted public services may be delivered at the lowest cost and price, resulting, a priori, in reduced government expenditures.

A second major reason why outsourcing policies should cut costs is the perception that the private sector is more efficient than the public sector, a view which justified much 
of the privatization movement (Clifton, Comín, \& Díaz-Fuentes, 2006). This may be so according to this line of thinking - because private firms may have greater incentives to innovate and cut costs (Shleifer \& Vishny, 1994). Incentives are thought to promote efficiency, for instance, if a manager personally benefits from improved performance, through company shares or salary improvements linked to efficiency gains (Andrews, Boyne, \& Walker, 2011). Davies (1971) argued that, in the case of public property/management, the costs and/or benefits of a decision are less borne by the decision maker, unlike under a scheme of private property rights.

On this basis, two theoretical expectations on government outsourcing effects can be derived from public choice and property rights models. First, spending on those public services exposed to competition and scheme of private property rights will decrease and, second, outsourcing will result in increased efficiency of public service provision. Based on the above discussion, it is conceivable to assume that implementing outsourcing policies could deliver significant reductions of government budgets.

\subsection{The alternative hypothesis: outsourcing may not lead to lower government spending} The assumption that cost savings and efficiency gains are passed back to the overall government budget, however, could be challenged from multiple perspectives, such as (i) the existence of high transaction costs, (ii) fiscal illusion, (iii) common pool problems, (iv) pressures from interest groups and, (v) negative externalities derived from outsourcing policies. In what follows we aim to briefly synthetize these arguments.

Firstly, a large body of scholars has expressed skepticism about the presumed advantages government outsourcing has on reduced public spending through the lens of transaction costs economics (Williamson, 1991; Williamson, 1999). Briefly, transaction costs theory focuses on different service characteristics that may block the effectiveness 
of outsourcing policies (Brown \& Potoski, 2005). Sources of potentially high costs associated with contracting out include asymmetric information, the management and supervision of contracts, “non-contractible” elements related to service delivery (such as in the case of confidence goods), contractual incompleteness and limited availability of competitive suppliers in the market (Girth, Hefetz, Johnston, \& Warner, 2012; Hefetz \& Warner, 2012; Sappington \& Stiglitz, 1987; Warner \& Hefetz, 2008). Following from this, it has also been argued that even if government contracting has positive effects over the short term, the potential cost savings from outsourcing may diminish or disappear over time by rising prices of the private sector companies due to the so-called "hold-up" problem (Domberger \& Jensen, 1997; Williamson, 1999). When contracts are highly complex or incomplete, governments may need to renegotiate the contract in the case of an unforeseen problem or event. This not only has costs, it also gives the private firm with its incentives to maximize profits - the opportunity to raise the prices it charges to governments (Jensen \& Stonecash, 2005). If goods or services are contracted out over the long-term, governments may irrevocably lose their capabilities as provider, increasing the bargaining power of the private provider(s).

A second potential source of adverse effects of government outsourcing policies on public spending is that outsourcing may generate some kind of fiscal illusion (Payton \& Kennedy, 2013). Briefly, fiscal illusion may arise when citizens overestimate the benefits of public spending and underestimate the costs of taxation (Buchanan \& Wagner, 1977; Wagner, 1976). In our case, outsourcing may hide the real costs of private service delivery from the public, particularly in a high transaction costs scenario. These hidden costs may result in a form of fiscal illusion which may support excess government spending since outsourcing policies might reduce the perceived price of public service delivery to citizens. Therefore, as a response to a potential perception of more efficient 
provision of public services, citizens/voters may increase their demand for public services, thus increasing government spending.

Closely related to the fiscal illusion approach is the idea that outsourcing may not necessarily reduce the size of the resource pool controlled by central governments (Benson, 1990). Following this logic, any expenditure savings from outsourced services are likely to be retained and reallocated within the government budget, since public officials are believed to respond to "budget maximizing” incentives. The upshot might be that spending on those services still controlled by the government could rise as a result of outsourcing (Boyne, 1998b), undermining, therefore, any overall cost savings derived from outsourced services.

Another strand of the literature on government outsourcing supports the view that outsourcing creates new interest groups, such as the contracting firms and their employees, which may increase the demand for those goods or services they sell to the government (see, for example, Benson, 1990). Following Olson (1982) and Mueller and Murrell (1986), among others, a greater number of interests groups is commonly associated with higher government outlays. The general argument here is that interest groups pursuing self-interests are able to influence policymakers in order to increase public spending for their own benefit. These anticipated influences of newly created interest groups as a result of implementing outsourcing policies may undermine, again, any overall expenditure reductions.

Finally, it has also been argued that potential cost savings and efficiency gains derived from outsourcing may not lead to lower government spending because of negative externalities associated with outsourcing policies, which may impose costs on other government organizations (Boyne, 1998a). For instance, if cost reductions and efficiency gains are a result of employing fewer staff (Boycko, Shleifer, \& Vishny, 1996), this might 
imply that extra costs due to unemployment benefits may eventually outweigh any savings resulting from staff reductions, since those reductions generally affect unskilled workers who may have more difficulties finding alternative jobs elsewhere (Boyne, 1998a).

Following all these lines of argument, it is possible that, though retaining the theoretical assumptions that competition and ownership lead to cost reductions in those services subject to competition and the discipline of private markets, outsourcing may not lead to lower spending in the government system as a whole. If true, this undermines the central justification used to promote outsourcing, making the policy much less attractive for taxpaying citizens, especially since outsourcing may augment the risk of service quality deterioration (Florio, 2014). In sum, economic theory seems to provide a valuable framework for assessing the impact of outsourcing on aggregate government expenditure, but theoretical predictions are mixed. The theoretical impact of outsourcing is therefore indeterminate and requires empirical investigation.

\section{Methodology}

To assess the outsourcing effects on public sector spending we use an unbalanced panel of 25 EU countries from 1990 to 2011. The following subsections include a description of the variables used in the analysis, main trends of government spending and government outsourcing, and the empirical specification.

\subsection{Data and variables}

We classified here the main variables into three categories; public expenditures, outsourcing indicator, and a set of control variables.

Public Sector Spending 
The dependent variable analysed is central government expenditures, measured by the ratio of total central government spending as a share of GDP. Figure 1 shows the main trends on public expenditures for each country. On average, the size of the public sector at the central level is substantially smaller in federal countries such as Germany and Spain, and also in some post-communist Central and Eastern European (CEE) countries such as Latvia, Lithuania, and Poland. Regarding the evolution of central government expenditures, different patterns can be seen. Data is complete for 10 countries, stretching across 1990-2011³ whilst, between 1995 and 2011, we have data for all 25. Looking at this group of 10 countries, seven of them reduced expenditure between the period 19902011, led by Italy, the Netherlands and Belgium, whilst Luxembourg, Finland, Denmark and the UK, continued to grow. Looking now at the 25 countries across 1995 to 2011, central government size decreased 2.43 percentage points across the whole period, with the Czech Republic, Sweden, Slovakia and Italy declining the most. However, there is a group of eight countries whose central expenditures slightly increased during the period under study, particularly Cyprus (see Figure 1).

[Figure 1 about here]

\section{Outsourcing Indicator}

The explanatory variable of interest is the percentage of central government spending that is allocated to non-government contractors. More specifically, outsourcing can be defined as the production of public goods and services by agents other than government

\footnotetext{
${ }^{3}$ Data for Germany starts in 1991.
} 
employees (Minicucci \& Donahue, 2004). Governments can outsource the production of public goods and services in two main ways: they can either purchase goods and services from the private sector or non-governmental organizations in order to include them in their own production chain (termed in the SNA "intermediate consumption"), or they can hire a company to directly provide public goods and services to the final consumer or citizen, termed in the SNA "social transfers in kind via market producers" (OECD, 2011). Our outsourcing indicator is based on the OECD (2011) "government outsourcing indicator" and is constructed using the Eurostat "Government revenue, expenditure and main aggregates" database, as the sum of intermediate consumption ${ }^{5}$ plus social transfers in kind via market producers $^{6}$ as a share of final government consumption ${ }^{7}$. Mathematically and following the European Commission (EC) notation:

$$
\text { Outsourcing }=\frac{P 2+(D .6311+D .63121+D .63131)}{P 3} \times 100
$$

Figure 2 shows the main trends related to government outsourcing. Data is available for 12 countries from 1990 to 2011 and all 25 from 1995 onwards. Between 1995 and 2011, central government outsourcing increased across all countries at an average of $1.74 \%$,

Countries with higher outsourcing ratios across this period are, on average, the UK, the Netherlands and Sweden, all of them showing averaged outsourcing ratios of about $50 \%$ of final government consumption. Those countries with lower averaged

\footnotetext{
${ }^{4}$ Following Pollitt (2013), one of the best sources of official data about government reforms is the OECD's annual publication Government at a glance, which has been frequently cited and used both by governments and academic studies.

${ }^{5}$ Intermediate Consumption is labeled by the European Commission (2011) as P2.

${ }^{6}$ According to the European Commission (2011) Social transfers in kind via market producers are labeled as D.6311 + D.63121 + D63131.

${ }^{7}$ Government final consumption is the sum of government consumption of labor, goods, services and fixed and fixed capital, labeled as P3 (European Commission, 2011).
} 
outsourcing ratios are Italy (19.16\%) and Luxembourg (23.89\%). Regarding the evolution of central government outsourcing, though it increased, on average, between 1995 and 2011, there are substantial variations among countries; while countries such as Germany, Portugal, Ireland, Latvia and the Netherlands show — by far — the largest increases in this period, other countries such as Estonia, Lithuania and Poland significantly decreased their outsourcing ratios. This may reflect the fact that reform efforts during early years of post-communism transition in CEE countries subsided somewhat from the 2000s (Drechsler, 2005). New Public Management (NPM) concepts, such as the implementation of outsourcing policies, were predominant at that time in Western European countries and international organizations such as the OECD, the IMF and the World Bank, countries and organizations from which early transition inspiration was drawn (Randma-Liiv, 2008). For instance, the Estonian transition was heavily based on NPM concepts but, today, Estonia seems to belong to the "strong opposers" to NPM-style reforms (Nemec, 2010, p.34). However, NPM-reform patterns — as regards content and timing — were not the same in all CEE countries (Bouckaert, Nakrošis, \& Nemec, 2011). For example, our data suggest that, in Latvia, outsourcing ratios started to grow from the 2000s, which confirms the view that NPM-style reforms were implemented in the later reform phases in Latvia (Bouckaert et al., 2011, p.18).

[Figure 2 about here]

\section{Control Variables}

Following the literature on determinants of public sector size, the following variables are included as control variables. First, to control for underlying economic trends, our 
extended models include the real GDP per capita growth and real GDP per capita, which may take Wagner`s Law (Wagner, 1911) into account, and the unemployment rate, which may control - alongside with GDP growth and GPD per capita - for the general macroeconomic environment. Second, we include three demographic variables which may control for the effect of demographics and economies of scale in the demand for public expenditure and provision of public services: the dependency ratio, which is the population under 14 years old plus the population over 65 years old, as a share of the population between 15 and 64 years old; an urbanity index, measured by the urban population as a share of the total population, and the population density. Third, we include a set of institutional and political variables which may affect public spending: an index of political fragmentation and the ideology of the ruling party. First, to account for the potential effect of political fragmentation we include a Herfindahl index of government concentration; building on the seminal work of Weingast, Shepsle and Johnsen (1981) and Shepsle and Weingast (1981) on common pool problems in policy making, the literature related to public spending determinants have devoted considerable attention to the idea that political fragmentation affects the amount of government spending. Finally, to control for the influence of ideology on public spending, we include in our model a dummy variable, left majority, which takes a value of 1 if left-wing parties control a clear majority of the cabinet posts (over $66.6 \%)^{8}$. Table 1 sets out the data sources and descriptive statistics.

[Table 1 about here]

\footnotetext{
${ }^{8}$ Left-wing denotes social democratic parties and political parties to the left of social democrats. For further details about this indicator, see Armingeon et al. (2013).
} 


\subsection{Empirical model}

A model to formally test whether government outsourcing leads to lower central government spending should relate public expenditures to the share of outsourced government activities and other potential determinants of government spending. The model can be specified as follows:

$$
y_{i t}=\beta x_{i t}+\gamma^{\prime} Z_{i t}+\mu_{i}+\delta_{t}+\epsilon_{i t}
$$

where $y_{i t}$ is the ratio of total expenditure as a share of GDP in country $i$ at time $t$; $\mathrm{x}_{i t}$ is the $i t t h$ observation of the outsourcing indicator; $Z_{i t}$ the $i t$ th observation on $P$ control variables, $\mu_{i}$ denotes country specific effects; $\delta_{\mathrm{t}}$ represents the specific time effect (common to all countries) and $\epsilon_{i t}$ the remainder disturbance term.

Our analysis proceeds as follows: To keep the maximum number of observations in the sample, we begin with a basic model specification which includes only as explanatory variables the outsourcing indicator and country and time specific effects (model I). Then, as robustness check, we estimate a model including also the full set of control variables (model II). Since panel data suffer usually from heteroskedasticiy and serial correlation issues, which can bias the standard errors and generate inefficiency in the coefficient estimates, models I and II are estimated using Beck and Katz's (1995) ordinary least squares with Panel Corrected Standard Errors (PCSE), and Parks’ (1967) Feasible Generalized Least Squares (FGLS) estimator.

Next, we address concerns about the potential endogeneity of the outsourcing indicator. Some studies suggest the possibility that increased public spending leads to increased outsourcing rates (see Pallesen, 2004), which means that our outsourcing 
indicator might be endogenous due to reverse causality (simultaneity) issues. Moreover, since the outsourcing indicator is constructed with fiscal variables, it might be simultaneously determined with the public sector size, which is also a fiscal variable. To address this endogeneity issue, we propose to complement our estimations with an instrumental variable approach using a two-stage least squares (2SLS) estimator.

Finally, following the recent literature on public sector size we estimate a model including the lagged dependent variable among the regressors to control for possible expenditure dynamics. When estimating dynamic models, it is important to take into account that the correlation between the lagged dependent variable and the error correction term may be a source of bias and inconsistency (Nickell, 1981). To overcome this, Arellano and Bond (1991) developed a Generalized Method of Moments (GMM) procedure. These authors suggested taking first differences of equation (2) to eliminate the individual specific effects, and then instrument the potentially endogenous right-hand side variables in the first-differenced equation using levels of the series lagged at least two periods. This estimator was originally developed for micro-panels, meaning samples with large cross-sectional units and a small number of time periods. In our sample, as common to studies using macroeconomic data, neither of the dimensions is large, which may affect the consistency of our results. Judson and Owen (1999), in a Monte Carlo experiment, found that in macro-panel environments when $\mathrm{T} \leq 20$ the GMM estimators perform relatively well, only outperformed by the corrected Least Squares Dummy Variable (LSDVC) estimator derived by Kiviet (1995). The LSDVC estimator performs an analytical correction of the LSDV bias in short panels based on an approximation of the finite-sample bias (see, Bruno, 2005a; Kiviet, 1995). Monte Carlo evidence supports the use of this estimator instead of GMM estimators when working with macro-panels. 
In this light, we propose to use this latter estimator while we will make use of the former one (GMM) for a robustness check.

\section{Results and Discussion}

Here we present the results of estimating the models presented in the previous section, before discussing their policy implications. The estimation results consistently indicate that outsourcing has not led, on average, to lower government expenditures at the central government level. Table 2 shows PCSE, FGLS and 2SLS estimates' results from our basic model (model I), which estimates government outsourcing effects based only on the most basic set of variables, an also our main model (model II), which includes those, $a$ priori, important control variables discussed in section 3.1.

Starting with the analysis without accounting for potential endogeneity issues, both models are estimated using PCSE and FGLS procedures. There has been some discussion about which estimator is preferable (see, Beck \& Katz, 1995; Chen, Lin, \& Reed, 2010). However, with our data set these two approaches yield similar results. The most important results are the parameter estimates for our outsourcing indicator. Both model specifications indicate that there is a positive and statistically significant relationship between the outsourcing ratio and government expenditures, the coefficients associated with the outsourcing ratio ranging from 0.13 to 0.21 in function of the model and the estimator employed.

These results could be questioned given that the relationship between outsourcing and government spending could be merely evidence of causality running from public spending to government outsourcing or just because there might be a simultaneous determination of both variables. To address these potential endogeneity issues, we also report in Table 2 the results using a 2SLS estimator, employing the second and third lags of the outsourcing indicator as instruments. Econometrically, the instruments must be 
sufficiently correlated with the potentially endogenous covariate (relevance criteria), but uncorrelated with the error term. In our case, Kleibergen-Paap (KP) under-identification and KP weak identification tests suggest that the selected instruments are relevant, and Hansen over-identification tests suggest that those instruments are valid (see Table 2). The 2SLS estimates of the outsourcing effect are still positive and significant in both models. This therefore bolsters our finding that that outsourcing policies have not led, on average, to lower government expenditure.

As for our control variables, PCSE, FGLS and 2SLS estimates report similar results. Regarding the variables controlling for economic trends, we find that unemployment is positively related to public spending, since an increase in the rate of unemployment tends to lead to increased spending on social policies, passive and active employment policies, and counter-cyclical fiscal policies. On the other hand, GDP growth is negatively related to public spending, suggesting that when real GDP grows, the size of the central government shrink; we do not find, therefore, evidence to support Wagner's (1911) Law for the period and countries under analysis. As regards ideological and institutional variables, the coefficient associated with the Herfindalh index of government concentration suggest that less fragmented governments are less likely to increase government spending during the period under analysis. The coefficient estimates of government ideology show that governments controlled by left-wing parties are more likely to increase public spending, though this effect does not seem to be statistically significant.

[Table 2 about here] 
As a final robustness check, we estimate the dynamic model discussed in section 3.2. Table 3 reports estimation results for both models using the aforementioned LSDVC ${ }^{9}$ and $\mathrm{GMM}^{10}$ estimators; the lagged dependent variable is always significant and takes positive values in all model specifications, which shows that government expenditures exhibit a dynamic pattern. As regards our main coefficient of interest, the outsourcing effect on public expenditures, the estimates are still positive in all model specifications, though the LSDVC estimates report slightly lower coefficients (about 0.08).

[Table 3 about here]

In sum, the results of all estimated models indicate that outsourcing has not led to lower government expenditure; moreover, we find evidence that outsourcing actually led, on average, to greater public spending at the central government level. What policy lessons can be extracted from these findings? Fundamentally, the outsourcing of public services - involving the transfer away from government and towards private agents the responsibility for producing and delivering public services - was justified principally by the ideas that the private sector could do the job more efficiency, generating cost savings for governments. For citizens, the benefits were two-fold: they would enjoy better quality public services whilst seeing a reduction in their tax contribution. Other potential advantages of outsourcing as a consequence of bringing them under private management was that competition would render public service providers more efficient, offering more choice to citizens, resulting in greater citizen satisfaction. Indeed, a host of studies have

\footnotetext{
${ }^{9}$ LSDVC estimations are computed using the $x t l s d v c$ routine developed by Bruno (2005b), initializing the bias correction by the Arellano and Bond estimator.

10 To avoid estimation bias due to the use of too many instruments (see, Roodman, 2009b), we restrict the instruments matrix, exclude time dummies and use only certain lags of the lagged expenditures covariate instead of all available lags for instruments (see table 3 notes). Hansen over-identification tests suggest that this approach is valid.
} 
already researched into the consequences of outsourcing as regards its potentially negative effects on issues such as: efficiency (Alonso, Clifton and Díaz-Fuentes, 2015b); citizen satisfaction with services (Clifton, Díaz-Fuentes and Fernández-Gutiérrez, 2016); social welfare (Sclar, 2015) and labour conditions, work-related stress and service quality (Hermann and Flecker, 2012). However, few studies had asked the whether the core justification for outsourcing - its reduction of government spending - could be confirmed empirically. Our results significantly undermine policy-makers' claims that outsourcing entails cost savings, at least, as a generalizable statement.

How could policy-makers use these findings? Firstly, the findings stress that outsourcing should not be promoted unequivocally as always bringing about cost savings. Secondly, however, this does not mean outsourcing never reduces public expenditure. This research, by analysing the effects of outsourcing at relatively high levels of aggregation, obscures the fact that outsourcing may well bring about savings in particular countries and sectors, but not in others. Hence, our finding coincides with ongoing discussions about the extent to which policy can be applied as one "single recipe” (onesize-fits-all approach), or, whether policy requires a more nuanced approach, guided by the understanding that policy works in particular sectoral/geographical/political situations, when a specific and often complex set of conditions are in place (see, Grindle, 2011; Rodrik, 1996). Given the central justification for outsourcing and our key finding, the lesson is that, in order for outsourcing to achieve what its advocates promise - reduced government spending - policy-makers must ensure specific preconditions are in place in order for outsourcing to deliver these expected savings. In this scenario, policymakers can conduct careful cost-benefit analysis, with a particular focus on those costs derived from contracts' drafting, managing and monitoring, negative externalities to other government organizations, potential "hold up” issues, and so on; in Prager and Desai’s 
(1996, p.185) words "contracting out must be implemented with the precision of a surgeon's scalpel, not with the brute force of the butcher's cleaver”.

\section{Conclusions}

Policy-makers working across multiple organizations, including the EC, the World Trade Organization and the OECD, continue to argue in favour of outsourcing as a means to reduce government spending on public services. The ongoing crisis that began in 2008 has augmented this need of governments to reduce expenditure on public services. Though outsourcing advocates insist the policy has a number of advantages such as augmented service efficiency and quality, the fundamental justification for outsourcing is its stated advantage in reducing government expenditure on public services. However, there remains a lack of empirical evidence demonstrating that outsourcing actually led to government savings in the scholarship on outsourcing. Though the empirical literature on government outsourcing effects is large, the vast majority of the empirical research did not take into account whether detected cost savings in particular services were translated to the government as a whole.

In this light, this paper sought to assess whether outsourcing public sector tasks actually led to reductions in government expenditure. The empirical findings consistently reject our null hypothesis, indicating that outsourcing was not associated with a reduction in public sector size at the central government level; in fact, outsourcing policies resulted in increased government expenditures. These results call into question the widespread assumption that contracting out public service production should result in lower costs or savings for governments. As we found overall expenditure actually increases and, given we are working at quite an aggregated level, we assume outsourcing sometimes reduces costs, but that overall, it does not. The major policy lesson here then is that policy-makers require information on the preconditions necessary in order that outsourcing is likely to 
generate cost savings, and, indeed, those preconditions where outsourcing is unlikely to generate cost savings, using a cost-benefit analysis approach.

Despite the strengths of the findings, there are limitations of our analysis that offer opportunities for further research. In particular, our study design does not allow us to precisely identify the mechanisms explaining the positive relationship between outsourcing and government spending. Unfortunately, due to the lack of reliable indicators it was not possible for us to disentangle those precise mechanisms on this occasion. Further quantitative research may help, therefore, to shed light on whether transaction costs, fiscal illusion, common pool problems, pressures from interest groups, or the existence of negative externalities matter most when explaining our findings.

For now, though, we can conclude that our study has not contributed empirical support for the on-going advocacy of government outsourcing as a policy prescription. 


\section{REFERENCES}

Alonso, J. M., Clifton, J., \& Díaz-Fuentes, D. (2015a). Did new public management matter? An empirical analysis of the outsourcing and decentralization effects on public sector size. Public Management Review, 17(5), 643-660.

Alonso, J. M., Clifton, J., \& Díaz-Fuentes, D. (2015b). The impact of New Public Management on efficiency: An analysis of Madrid's hospitals. Health Policy, 119(3), 333-340.

Anderson, D., Hunt, B., \& Snudden, S. (2014). Fiscal consolidation in the euro area: How much pain can structural reforms ease? Journal of Policy Modeling, 36(5), 785-799.

Andrews, R., Boyne, G., \& Walker, R. (2011). Dimensions of publicness and organizational performance: A review of the evidence. Journal of Public Administration Research and Theory, 21(suppl 3), i301-i319.

Arellano, M., \& Bond, S. (1991). Some tests of specification for panel data: Monte Carlo evidence and an application to employment equations. The Review of Economic Studies, 58(2), 277-297.

Armingeon, K., Careja, R., Knöpfel, L., Weisstanner, D., Engler, S., Potolidis, P., \& Gerber, M. (2013). Comparative Political Data Set III 1990-2011. Bern: Institute of Political Science, University of Berne.

Beck, T., Clarke, G., Groff, A., Keefer, P., \& Walsh, P. (2001). New tools in comparative political economy: The Database of Political Institutions. The World Bank Economic Review, 15(1), 165-176. 
Beck, N., \& Katz, J. N. (1995). What to do (and not to do) with time-series crosssection data. American Political Science Review, 89(03), 634-647.

Bel, G., \& Warner, M. (2015). Factors explaining inter-municipal cooperation in service delivery: a meta-regression analysis. Journal of Economic Policy Reform, 19(2), 91-115.

Bel, G., Fageda, X., \& Warner, M. E. (2010). Is private production of public services cheaper than public production? A meta-regression analysis of solid waste and water services. Journal of Policy Analysis and Management, 29(3), 553-577.

Benson, B. L. (1990). The enterprise of law: Justice without the state. San Francisco: Pacific Research Institute for Public Policy.

Boardman, A. E., Vining, A. R., \& Weimer, D. L. (2016). The long-run effects of privatization on productivity: Evidence from Canada. Journal of Policy Modeling. Ahead-of-print.

Bouckaert, G., Nakrošis, V., \& Nemec, J. (2011). Public administration and management reforms in CEE: Main trajectories and results. NISPAcee Journal of Public Administration and Policy, 4(1), 9-29.

Boycko, M., Shleifer, A., \& Vishny, R. W. (1996). A theory of privatisation. The Economic Journal, 106(435), 309-319.

Boyne, G. A. (1998a). Bureaucratic theory meets reality: Public choice and service contracting in US local government. Public Administration Review, 58(6), 474-484. 
Boyne, G. A. (1998b). Competitive tendering in local government: A review of theory and evidence. Public Administration, 76(4), 695-712.

Brown, T. L., \& Potoski, M. (2005). Transaction costs and contracting: The practitioner perspective. Public Performance \& Management Review, 28(3), 326-351.

Bruno, G. S. (2005a). Approximating the bias of the LSDV estimator for dynamic unbalanced panel data models. Economics Letters, 87(3), 361-366.

Bruno, G. S. (2005b). XTLSDVC: Stata module to estimate bias corrected LSDV dynamic panel data models. Statistical Software Components,

Buchanan, J., \& Wagner, R. (1977). Democracy in deficit Acad. Press.

Chen, X., Lin, S., \& Reed, W. R. (2010). A Monte Carlo evaluation of the efficiency of the PCSE estimator. Applied Economics Letters, 17(1), 7-10.

Clifton, J., Díaz-Fuentes, D., \& Fernández-Gutiérrez, M. (2016). Public infrastructure services in the European Union: Challenges for territorial cohesion. Regional Studies, 50(2), 358-373.

Clifton, J., Comín, F., \& Díaz-Fuentes, D. (2006). Privatizing public enterprises in the European Union 1960-2002: Ideological, pragmatic, inevitable? Journal of European Public Policy, 13(5), 736-756.

Davies, D. G. (1971). The efficiency of public versus private firms, the case of Australia's two airlines. Journal of Law and Economics, 14(1), 149-165.

Domberger, S., \& Jensen, P. (1997). Contracting out by the public sector: Theory, evidence, prospects. Oxford Review of Economic Policy, 13(4), 67-78. 
Domberger, S., \& Rimmer, S. (1994). Competitive tendering and contracting in the public sector: A survey. International Journal of the Economics of Business, 1(3), 439-453.

Drechsler, W. (2005). The re-emergence of “Weberian” public administration after the fall of new public management: The central and eastern European perspective. Administrative Culture, (06), 94-108.

European Commission. (2011). Manual on sources and methods for the compilation of COFOG statistics classification of the functions of government (COFOG). Luxembourg: Publications Office of the European Union.

Ferré, M. (2008). Fiscal policy coordination in the EMU. Journal of Policy Modeling, 30(2), 221-235.

Florio, M. (2014). Contemporary public enterprises: innovation, accountability, governance. Journal of Economic Policy Reform. 17(3), 201-2018.

Girth, A. M., Hefetz, A., Johnston, J. M., \& Warner, M. E. (2012). Outsourcing public service delivery: Management responses in non-competitive markets. Public Administration Review, 72(6), 887-900.

Grindle, M. S. (2011). Governance reform: The new analytics of next steps. Governance, 24(3), 415-418.

Hefetz, A., \& Warner, M. E. (2012). Contracting or public delivery? The importance of service, market, and management characteristics. Journal of Public Administration Research and Theory, 22(2), 289-317. 
Hermann, C. and Flecker, J. (2012). Privatization of Public Services. Impacts for Employment, Working Conditions, and Service Quality in Europe. Routledge: New York, London, 213pp.

Hodge, G. A. (2000). Privatization: An international review of performance. Boulder, CO: Westview Press.

Jensen, P. H., \& Stonecash, R. E. (2005). Incentives and the efficiency of public sectoroutsourcing contracts. Journal of Economic Surveys, 19(5), 767-787.

Judson, R. A., \& Owen, A. L. (1999). Estimating dynamic panel data models: A guide for macroeconomists. Economics Letters, 65(1), 9-15.

Kiviet, J. F. (1995). On bias, inconsistency, and efficiency of various estimators in dynamic panel data models. Journal of Econometrics, 68(1), 53-78.

Minicucci, S., \& Donahue, J. D. (2004). A simple estimation method for aggregate government outsourcing. Journal of Policy Analysis and Management, 23(3), 489507.

Mueller, D. C., \& Murrell, P. (1986). Interest groups and the size of government. Public Choice, 48(2), 125-145.

Nemec, J. (2010). New public management and its implementation in CEE: What do we know and where do we go? NISPAcee Journal of Public Administration and Policy, 3(1), 31-52.

Nickell, S. (1981). Biases in dynamic models with fixed effects. Econometrica: Journal of the Econometric Society, 49(6), 1417-1426. 
Niskanen, W. A. (1971). Bureaucracy and representative government. Chicago, Ill.:

Aldine.

OECD. (2007). Competition Policy and Concessions. Paris: Policy Brief.

OECD. (2011). Government at a glance 2011. Paris: OECD Publishing.

OECD. (2013). Government at a glance 2013. Paris: OECD publishing.

Olson, M. (1982). The rise and decline of nations: Economic growth, stagflation, and social rigidities. New Haven: Yale University Press.

Pallesen, T. (2004). A political perspective on contracting out: The politics of good times. Experiences from Danish local governments. Governance, 17(4), 573-587.

Parks, R. W. (1967). Efficient estimation of a system of regression equations when disturbances are both serially and contemporaneously correlated. Journal of the American Statistical Association, 62(318), 500-509.

Payton, S. B., \& Kennedy, S. S. (2013). Fiscal magic outsourcing and the taxing power. State and Local Government Review, 45(3), 189-195.

Pollitt, C. (2013). Back in the OECD... an oblique comment on the World Bank’s Better Results from Public Sector Institutions. International Review of Administrative Sciences, 79(3), 406-412.

Prager, J., \& Desai, S. (1996). Privatizing local government operations: Lessons from federal contracting out methodology. Public Productivity \& Management Review, 20(2), 185-203. 
Randma-Liiv, T. (2008). New public management versus the neo-weberian state in central and eastern Europe. The NISPAcee Journal of Public Administration and Policy, 1(2), 49-71.

Rodrik, D. (1996). Understanding economic policy reform. Journal of Economic Literature, 34(1), 9-41.

Roodman, D. (2009a). How to do xtabond2: An introduction to difference and system GMM in Stata. Stata Journal, 9(1), 86-136.

Roodman, D. (2009b). A note on the theme of too many instruments*. Oxford Bulletin of Economics and Statistics, 71(1), 135-158.

Ruiz-Villaverde, A., Picazo-Tadeo, A. J., \& González-Gómez, F. (2015). The ‘social choice’of privatising urban water services: A case study of Madrid in Spain. Journal of Policy Modeling, 37(4), 616-629.

Sappington, D. E., \& Stiglitz, J. E. (1987). Privatization, information and incentives. Journal of Policy Analysis and Management, 6(4), 567-585.

Savas, E. S. (2000). Privatization and public-private partnerships. New Jersey: Chatham House.

Sclar, E. (2015). The political economics of investment utopia: public-private partnerships for urban infrastructure finance. Journal of Economic Policy Reform, 18(1), 1-15.

Shepsle, K. A., \& Weingast, B. R. (1981). Political preferences for the pork barrel: A generalization. American Journal of Political Science, 25(1), 96-111. 
Shleifer, A., \& Vishny, R. W. (1994). The politics of market socialism. The Journal of Economic Perspectives, 8(2), 165-176.

Vaughan-Whitehead, D. (2013). Public sector shock in Europe: Between structural reforms and quantitative adjustment. In D. Vaughan-Whitehead (Ed.), Public Sector shock. The impact of policy retrenchment in Europe. Cheltenham: Edward Elgar.

Wagner, A. (1911). Staat in nationalokonomischer hinsicht. Handwörterbuch der staatswissenscha en. Jena: Fischer.

Wagner, R. E. (1976). Revenue structure, fiscal illusion, and budgetary choice. Public Choice, 25(1), 45-61.

Warner, M. E., \& Hefetz, A. (2008). Managing markets for public service: The role of mixed public-private delivery of city services. Public Administration Review, 68(1), 155-166.

Warner, M. E., \& Clifton, J. (2014). Marketisation, public services and the city: The potential for polanyian counter movements. Cambridge Journal of Regions, Economy and Society, 7(1), 45-61.

Weingast, B. R., Shepsle, K. A., \& Johnsen, C. (1981). The political economy of benefits and costs: A neoclassical approach to distributive politics. The Journal of Political Economy, 89(4), 642-664.

Williamson, O. E. (1991). Comparative economic organization: The analysis of discrete structural alternatives. Administrative Science Quarterly, 36(2), 269-296. 
Williamson, O. E. (1999). Public and private bureaucracies: A transaction cost economics perspectives. Journal of Law, Economics, and Organization, 15(1), 306342. 
Figure 1. Central government spending as a share of GDP

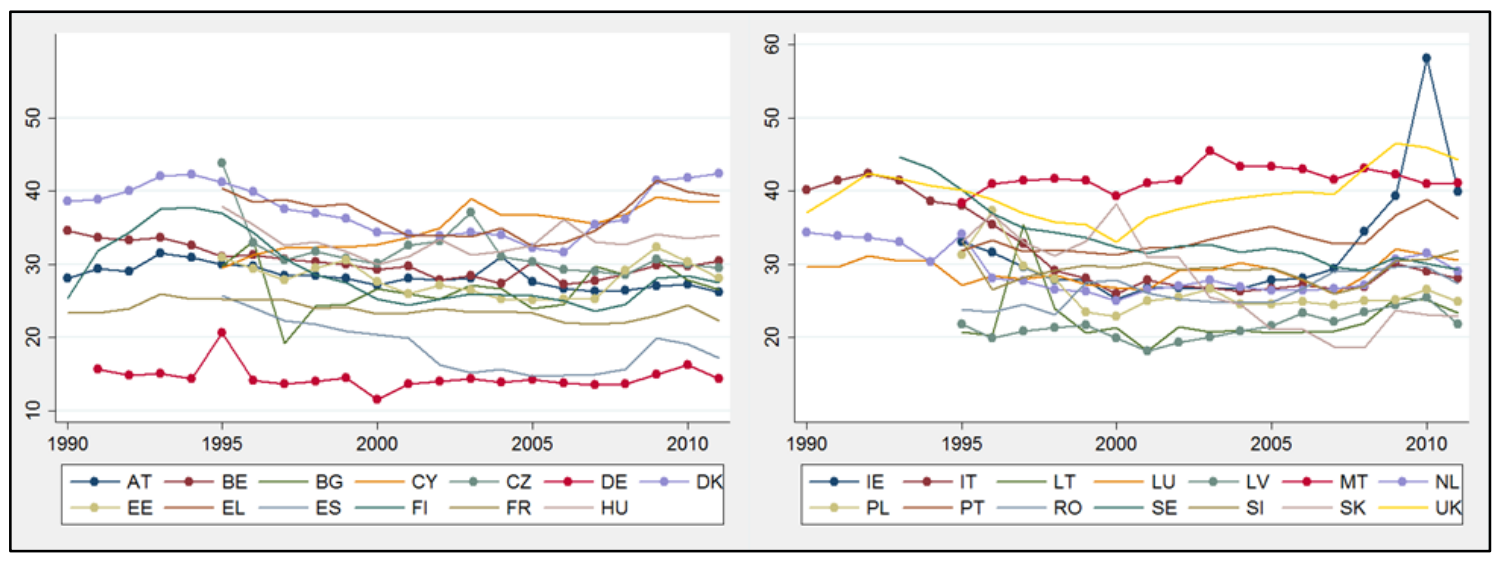

Source: Eurostat.

Figure 2. Central government outsourcing as a share of final consumption

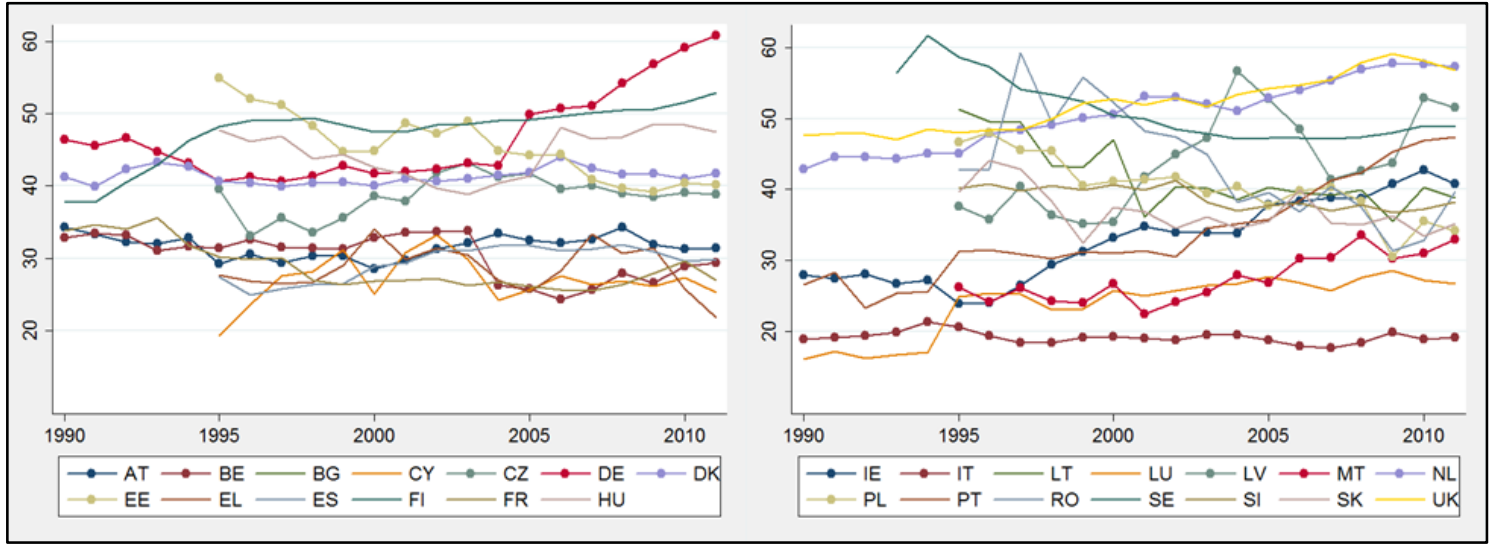

Source: Authors' calculations based on Eurostat data. 
Table 1. Descriptive statistics and data sources

\begin{tabular}{llrrrr}
\hline Variable & Source & Obs. & Mean & Std. Dev. & VIF \\
\hline Central gov. Size & Eurostat & 476 & 29.770 & 7.126 & \\
Outsourcing ratio & Own calculations based & 487 & 37.295 & 10.076 & 1.15 \\
& on Eurostat data & & & & \\
Unemployment rate & Eurostat/OECD & 479 & 8.516 & 4.029 & 1.46 \\
GDP per capita & Eurostat & 489 & 20631.49 & 12419.15 & 2.05 \\
GDP growth & Eurostat & 472 & 2.254 & 4.118 & 1.09 \\
Urban population & World Bank & 550 & 71.914 & 11.663 & 2.47 \\
Dependency ratio & World Bank & 550 & 48.734 & 3.781 & 1.78 \\
Population Density & World Bank & 550 & 175.706 & 234.417 & 1.86 \\
Left majority & CPDS III & 550 & 0.244 & 0.430 & 1.25 \\
Gov. concentration & DPI & 536 & 0.644 & 0.262 & 1.50 \\
\hline
\end{tabular}

Notes: VIF refers to the Variance Inflation Factor. Variables expressed in percentage points except GDP per capita (euro per inhabitant), Population density (inhabitants per square kilometer), Left majority (dummy) and Government concentration (Herfindahl Index). Variables constructed from data collected from five different data sources: Eurostat’s “Annual Government Finance Statistics” database, OECD’s Economic Outlook nº 93, World Bank’s ‘World Development Indicators’ database, Comparative Political Dataset III 1990-2011 (Armingeon et al., 2013) and Database of Political Institutions 1975-2012 (Beck et al., 2001). 
Table 2. Estimates of outsourcing effects on central government spending

\begin{tabular}{|c|c|c|c|c|c|c|}
\hline & \multicolumn{3}{|c|}{ Model I } & \multicolumn{3}{|c|}{ Model II } \\
\hline & PCSE & FGLE & $2 S L S$ & PCSE & FGLE & $2 S L S$ \\
\hline \multirow[t]{2}{*}{ Outsourcing ratio } & $0.198 * * *$ & $0.129 * * *$ & $0.269 * * *$ & $0.208 * * *$ & $0.149 * * *$ & $0.222 * * *$ \\
\hline & $(0.047)$ & $(0.032)$ & $(0.066)$ & $(0.049)$ & $(0.033)$ & $(0.076)$ \\
\hline \multirow[t]{2}{*}{ Unemployment rate } & & & & $0.222 * * *$ & $0.193^{* * *}$ & $0.343^{* * *}$ \\
\hline & & & & $(0.081)$ & $(0.056)$ & $(0.081)$ \\
\hline \multirow[t]{2}{*}{ GDP per capita } & & & & 0.000 & 0.000 & 0.000 \\
\hline & & & & $(0.000)$ & $(0.000)$ & $(0.000)$ \\
\hline \multirow[t]{2}{*}{ GDP growth } & & & & $-0.142 * * *$ & $-0.101 * * *$ & $-0.268 * * *$ \\
\hline & & & & $(0.054)$ & $(0.032)$ & $(0.065)$ \\
\hline \multirow[t]{2}{*}{ Urban population } & & & & 0.116 & 0.059 & $0.247 * *$ \\
\hline & & & & $(0.122)$ & (0.119) & $(0.122)$ \\
\hline \multirow[t]{2}{*}{ Dependency ratio } & & & & 0.144 & 0.077 & -0.064 \\
\hline & & & & $(0.124)$ & $(0.102)$ & $(0.099)$ \\
\hline \multirow[t]{2}{*}{ Population Density } & & & & 0.000 & 0.009 & 0.010 \\
\hline & & & & $(0.028)$ & $(0.025)$ & $(0.022)$ \\
\hline \multirow[t]{2}{*}{ Left majority } & & & & 0.329 & 0.204 & $0.641^{*}$ \\
\hline & & & & $(0.285)$ & $(0.303)$ & $(0.362)$ \\
\hline \multirow[t]{2}{*}{ Gov. concentration } & & & & $-2.726 * *$ & $-2.346 * * *$ & $-3.197 * * *$ \\
\hline & & & & $(1.102)$ & $(0.842)$ & (1.215) \\
\hline Observations & 476 & 476 & 408 & 438 & 438 & 394 \\
\hline Groups & 25 & 25 & 25 & 25 & 25 & 25 \\
\hline Country effects & Yes & Yes & Yes & Yes & Yes & Yes \\
\hline Time effects & Yes & Yes & Yes & Yes & Yes & Yes \\
\hline K-P LM Statistic & & & 74.228 & & & 61.905 \\
\hline K-P Wald F Statistic & & & 92.803 & & & 64.540 \\
\hline Hansen-J-Statistic & & & 2.073 & & & 0.106 \\
\hline Wald Chi2 & 50434.61 & 1379.73 & & $4.85 \mathrm{E}+06$ & 1826.51 & \\
\hline
\end{tabular}

Notes: The asterisks ***,**, and * denote significance at the $1 \%, 5 \%$, and $10 \%$ levels, respectively. Robust standard errors reported in parentheses. 
Table 3. Dynamic estimates of outsourcing effects on central government spending

\begin{tabular}{|c|c|c|c|c|}
\hline & & el I & & lel II \\
\hline & LSDVC & GMM & LSDVC & GMM \\
\hline Gov. Spending $\mathrm{t}_{\mathrm{t}-1}$ & $0.713^{* * *}$ & $0.861^{* * *}$ & $0.679 * * *$ & $0.706 * * *$ \\
\hline & $(0.040)$ & $(0.075)$ & $(0.043)$ & $(0.154)$ \\
\hline Outsourcing ratio & $0.083^{* * *}$ & $0.211^{* * *}$ & $0.082 * *$ & $0.248 * * *$ \\
\hline & $(0.029)$ & $(0.081)$ & $(0.034)$ & $(0.062)$ \\
\hline Unemployment rate & & & 0.041 & 0.014 \\
\hline & & & $(0.055)$ & $(0.092)$ \\
\hline GDP per capita & & & 0.000 & 0.000 \\
\hline & & & $(0.000)$ & $(0.000)$ \\
\hline GDP growth & & & $-0.212^{* * *}$ & $-0.225 * * *$ \\
\hline & & & $(0.047)$ & $(0.045)$ \\
\hline Urban population & & & 0.071 & -0.322 \\
\hline & & & $(0.105)$ & $(0.228)$ \\
\hline Dependency ratio & & & 0.027 & -0.165 \\
\hline & & & $(0.074)$ & $(0.208)$ \\
\hline Population Density & & & -0.010 & -0.001 \\
\hline & & & $(0.023)$ & $(0.042)$ \\
\hline Left majority & & & $0.624 *$ & -0.143 \\
\hline & & & $(0.342)$ & $(0.563)$ \\
\hline Gov. concentration & & & $-1.906 * *$ & -0.284 \\
\hline & & & $(0.928)$ & $(0.919)$ \\
\hline Observations & 451 & 426 & 426 & 401 \\
\hline Groups & 25 & 25 & 25 & 25 \\
\hline Country effects & Yes & No & Yes & No \\
\hline Time effects & Yes & No & Yes & No \\
\hline Instruments & & 21 & & 22 \\
\hline Hansen J- Stat & & 21.13 & & 14.12 \\
\hline Wald-Chi2 & & 150.5 & & 174.13 \\
\hline
\end{tabular}

Notes: The asterisks $* * *, * *$, and $*$ denote significance at the $1 \%, 5 \%$, and $10 \%$ levels, respectively. Robust standard errors reported in parentheses. LSDVC standard errors are obtained through 5000 bootstrap replications. LSDVC bias correction initialized by Arellano and Bond estimator. For GMM estimates the size of the instrument matrix is restricted in both models using the collapse option in Stata command xtabond2 (Roodman, 2009a), and number of lags are set between 2 and 14 in model II. 